\title{
Fisheries Enforcement on the High Seas of the Arctic Ocean: Gaps, Solutions and the Potential Contribution of the European Union and its Member States
}

\author{
Efthymios Papastavridis \\ Post-doctoral Research Assistant in Law of the Sea, Faculty of Law, University of Oxford; Oxford \\ Martin Fellow, University of Oxford, Oxford, UK
}

\begin{abstract}
Although there is no fishing activity within the central Arctic Ocean at present, commercial fishing activity does occur in the high seas areas of the North Atlantic and North Pacific, and within the exclusive economic zone of the Arctic coastal States. Climate change will most probably lead to an increase in fishing activity, through the reduction in sea ice, opening up new areas of the Arctic to fisheries, including the Central Arctic Ocean. This prospect has fuelled intensive negotiations - still ongoing - for the signing of a legally binding agreement to prevent unregulated fisheries therein. What seems missing, though, from both the ongoing negotiations on this agreement and the scholarly literature is reference to fisheries enforcement in the Arctic. Accordingly, this article identifies the most effective tools that could be employed for fisheries enforcement purposes, including port and flag State measures, and addresses their potential application in the Arctic.
\end{abstract}

\section{Keywords}

fisheries enforcement - Arctic - high seas - European Union (EU)

\section{Introduction}


Although there is no fishing activity within the Central Arctic Ocean at present, commercial fishing activity does occur in the surrounding areas. Specifically, large-scale commercial fisheries are taking place in the Barents and Bering Seas, but the fisheries in the Arctic Ocean are essentially limited to small-scale subsistence fisheries in Arctic coastal States' maritime zones. ${ }^{1}$ However, climate change will most likely change the picture, through the reduction in sea ice, which will open up new areas of the Arctic Ocean to fisheries, including areas of the Central Arctic Ocean, and through likely changes to the composition of fisheries. ${ }^{2}$ Moreover, it is observed that sea-ice regression in the Arctic leads to the interconnection of the North Pacific and the North Atlantic Oceans with the result that invasive species are settled in the Arctic in recent years, such as snow crab (Chionoecetes opilio) in the Barents Sea. ${ }^{3}$

Currently, there can be no safe prognosis on the exact consequences of such increase in fishing activities on the marine environment of the Arctic Ocean. Yet, it is not likely to be fundamentally different from impacts on the marine environment and biodiversity in other parts of the globe, where capture fisheries are generally at or exceeding the limits of sustainable fisheries. The declining global marine catch over the last few years, combined with the physical harm caused by the often highly destructive methods used for fishing, such as bottom trawling, have had, in many parts of the world, a severe impact on the marine

\footnotetext{
* I am grateful to Professor Catherine Redgwell (University of Oxford) for having read and commented on drafts of this work, as well as to the anonymous referee for the useful remarks. Needless to say that the responsibility for any error or omission lies exclusively with the author. The research leading to this article has received funding from the Oxford Martin School Programme for Sustainable Oceans, Oxford Martin School, University of Oxford. Email: efthymios.papastavridis@law.ox.ac.uk.

${ }^{1}$ See EJ Molenaar, 'International Regulation of Central Arctic Ocean Fisheries', in M Nordquist, N Moore and R Long (eds), Challenges of the Changing Arctic: Continental Shelf Navigation and Fisheries (Brill, Leiden, 2016) 429-464, at pp. 433-4.

2 As the Arctic Climate Impact Assessment noted: 'a moderate warming will improve the conditions for some of the most important commercial fish stocks. This is most likely to be due to enhanced levels of primary and secondary production resulting from reduced sea-ice cover and more extensive habitat areas for subarctic species such as cod and herring'; see Arctic Climate Impact Assessment (Cambridge University Press, Cambridge, 2005) 770.

${ }^{3}$ See MS Wisz, O Broennimann, P Grønkjær, RR Møller, SM Olsen, D Swingedouw, RB Hedeholm, EE Nielsen, A Guisan, and L Pellissier, 'Arctic Warming Will Promote AtlanticPacific Fish Interchange', Nature Climate Change, 26 January 2015; as cited in Molenaar (n 1), at p. 430.
} 
ecosystem. This is also possible to occur in the Arctic. ${ }^{4}$ Indeed, it is already known that overfishing poses a serious threat to fish populations in the Arctic. Additionally, the effects of other human activities that might increase as a result of climate change have to be borne in mind: shipping and extractive activities in particular may spatially compete with fishing or have an impact on them, e.g., by pollution. ${ }^{5}$

The potential for large-scale, commercially viable fisheries in the Arctic Ocean has fuelled discussions, not only on an academic, but also on an inter-State level. Indeed, as from early 2014, the five Arctic Ocean coastal States - Canada, Denmark/Greenland, Norway, the Russian Federation, and the United States (Arctic Five) - have engaged in serious multilateral negotiations on Central Arctic Ocean fisheries. The outcome of these negotiations has been, first, the signing by the Arctic Five of a non-binding Declaration concerning the Prevention of Unregulated High Seas Fishing in the Central Arctic Ocean on 16 July 2015 in Oslo ('Oslo Declaration'), ${ }^{6}$ effectively creating a moratorium on commercial fishing for the time being. This was followed by another round of negotiations still ongoing at the time of writing (December 2017) - for a binding agreement, this time with the participation of five more States or entities (the Arctic Five plus Five: China, Iceland, Japan, Korea and the European Union (EU)). ${ }^{7}$

Against this backdrop, this article addresses an issue that has escaped the attention of the scholarly literature, as well as of the above-mentioned negotiations, namely fisheries enforcement in the high seas areas of the Arctic Ocean. Arguably, any conservation and management measure (CMM) concerning Arctic fisheries must have an enforcement component to be effective. In other

\footnotetext{
${ }^{4}$ N Liu and E Kirk, 'The European Union's Potential Contribution to Protect Marine Biodiversity in the Changing Arctic: A Roadmap' (2015) 30(2) International Journal of Marine and Coastal Law (IJMCL) 255-284, at p. 268.

${ }^{5}$ See EJ Molenaar, 'Arctic Fisheries Conservation and Management: Initial Steps of Reform of the International Legal Framework' (2009) 1 The Yearbook of Polar Law 427-464, at p. 433. 6 Available

https://www.regjeringen.no/globalassets/departementene/ud/vedlegg/folkerett/declaration-onarctic-fisheries-16-july-2015.pdf; accessed 7 August 2017. For comment, see S Ryder, 'Declaration concerning the Prevention of Unregulated High Seas Fishing in the Central Arctic Ocean' in JCLOS Blog, 11 August 2015, available at http://site.uit.no/jclos/2015/08/11/thedeclaration-concerning-the-prevention-of-unregulated-high-seas-fishing-in-the-central-arcticocean/\#more-122; accessed 7 August 2017.

${ }^{7}$ See Draft Agreement to Prevent Unregulated High Seas Fisheries in the Central Arctic Ocean' (hereinafter: Draft Agreement) (on file with the author).
} 
words, CMMs should be complemented with certain monitoring, control and surveillance (MCS) tools, ${ }^{8}$ which would permit their enforcement ${ }^{9}$ and would prevent any Illegal, Unreported and Unregulated fishing (IUU fishing) in the region. ${ }^{10}$ Admittedly, as far as the high seas areas of the Central Arctic are concerned, a fisheries enforcement analysis seems currently to be a sheer academic exercise; however, it does have relevance for other high seas areas in the region, like the 'Loophole' in the Barents Sea and the 'Banana Hole' in the Norwegian Sea. It will definitely be of relevance when the first fishing vessels are able to access the Central Arctic Ocean.

This article examines the legal framework concerning MCS and enforcement tools in the Arctic, with particular emphasis placed on enforcement of fisheries laws and regulations on the high seas. The research question thus unfolds as follows: what are the means available under international law to prevent or combat IUU fishing on the high seas of the Arctic Ocean, particularly in the Central Arctic Ocean? Certainly, questions of enforcement may arise also in areas within national jurisdiction. However, in cases of illegal fishing within territorial waters and the exclusive economic zone (EEZ), coastal States' enforcement jurisdiction over such incidents is well embedded in international law $^{11}$ and is thus not considered further here.

\footnotetext{
${ }^{8}$ In a Technical Paper, the Food and Agriculture Organization (FAO) defines MCS as having three distinct, but interrelated components: a) Monitoring - the continuous requirement for the measurement of fishing effort characteristics and resource yield; b) Control - the regulatory conditions under which the exploitation of the resources may be conducted; and c) Surveillance the degree and types of observations required to maintain compliance with the regulatory controls imposed on fishing activities; see P Flewwelling, An Introduction to Monitoring, Control and Surveillance Systems for Capture Fisheries, FAO Technical Paper No. 338 (FAO, Rome, 2004) 3.

${ }_{9}^{9}$ MCS should be distinguished from enforcement powers or enforcement jurisdiction, which, by reference to Article 73 of the United Nations Convention on the Law of the Sea (LOSC), denotes 'such measures, including boarding, inspection, arrest and judicial proceedings, as may be necessary to ensure compliance with the laws and regulations adopted [by the coastal State] in conformity with this Convention'. The difference lies in the coercive nature of the measures that states may take for enforcement purposes (emphasis added).

${ }^{10}$ For the definition of IUU fishing see the International Plan of Action to Prevent, Deter and Eliminate Illegal, Unreported and Unregulated Fishing (adopted by the FAO Committee on Fisheries on 2 March 2001 and endorsed by the FAO Council on 23 June 2001); available at http://www.fao.org/docrep/003/y1224e/y1224e00.htm; accessed 7 August 2017 (hereinafter: IPOA-IUU).

${ }^{11}$ See, inter alia, LOSC Articles 21 (d), (e) and 25 (1) regarding territorial waters and LOSC Article 73 regarding the EEZ. See in general I Shearer, 'Problems of Jurisdiction and Law Enforcement against Delinquent Vessels' (1986) 35(2) International \& Comparative Law Quarterly 320-343 and E Papastavridis, 'Crimes at Sea: A Law of the Sea Perspective', in E
} 
Accordingly, after providing a concise overview of the current regime of fisheries in the Arctic and of the draft agreement on the Central Arctic Ocean, this article focusses on the existing and potentially future MCS and enforcement tools under the international law of the sea, as well as under the existing regional fisheries management organizations (RFMOs) in the region to combat IUU fishing on the high seas. Such tools include, inter alia: port State control measures; flag State measures, like vessel registration, authorisation to fish and global registry of fishing vessels; sanctions against IUU vessels and flag States; and at sea inspections and hot pursuits. An exhaustive analysis of all the potential tools and their practical ramifications is beyond the scope of the present article; rather its purpose is to identify gaps and propose solutions and best practices to this end, in view of past experiences in the region and beyond.

In this context, it is submitted that the EU and its Member States may play an active role in fisheries enforcement in the region. Although it is true that no EU Member State is a coastal State of the Arctic Ocean (Greenland became governmentally autonomous within Denmark ${ }^{12}$ and is not part of the $\mathrm{EU}^{13}$ ), the EU does have some ties with the Arctic. Three Arctic countries are EU Member States (Denmark, Sweden and Finland) and the EU maintains close relations with Iceland and Norway through the European Economic Area (EEA). ${ }^{14}$ For many years EU vessels have fished in most of those areas of the Arctic where the absence of sea ice currently permits commercial fishing, either in areas of EEZ under access agreements with Greenland, Iceland and Norway ${ }^{15}$ or in two high seas enclaves in the Norwegian and Barents Seas, the 'Banana Hole' and the

Papastavridis and K Trapp (eds), La Criminalité en Mer/Crimes at Sea, Hague Academy of International Law (Martinus Nijhoff Publishers, Leiden, 2014) 3-52.

12 Art. 22 of Act No. 473/2009 on Greenland's Self-Government; available at naalakkersuisut.gl/ /media/Nanoq/Files/Attached\%20Files/Engelske-

tekster/Act\%20on\%20Greenland.pdf; accessed 7 August 2017.

13 Treaty amending, with regard to Greenland, the Treaties Establishing the European Communities [1985] OJ L29/1.

14 The Agreement on the European Economic Area, which entered into force on 1 January 1994, brings together the EU Member States and the three EEA EFTA States - Iceland, Liechtenstein and Norway — in a single market, referred to as the "Internal Market"; available at www.efta.int/media/documents/legal-texts/eea/the-eea-

agreement/Main\%20Text\%20of\%20the\%20Agreement/EEAagreement.pdf; accessed 20 August 2017.

${ }^{15}$ For details, see R Churchill and D Owen, The EC Common Fisheries Policy (Oxford University Press, Oxford, 2010) 333-340. 
'Loophole', respectively, in accordance with the regimes applying in those areas. ${ }^{16}$ Moreover, as reported by the EU, one-third of fish caught in the Arctic are sold on the European market. ${ }^{17}$ It readily appears that the EU has a strong say on the current and the future - as a negotiating party to the new agreement - fisheries landscape in the Arctic. ${ }^{18}$ Thus, in analysing the measures that could be adopted to ensure fisheries enforcement in the Arctic, this article refers to the EU and how it may contribute to this effort.

\section{Fisheries in the Arctic Ocean: An Overview}

\section{The Arctic Ocean Fisheries}

The Arctic Ocean is the smallest of the world's oceans and like the Mediterranean and the Caribbean Seas, is closely confined by continents. The southernmost boundary of the Arctic Ocean is subject to varying definitions which include the Arctic Circle (an imaginary circle around the globe at $66^{\circ} 32^{\prime} \mathrm{N}$ ), the $10^{\circ} \mathrm{C}$ isotherm (the most southerly location where the mean temperature of the warmest month of the year is below $10^{\circ} \mathrm{C}$ ) and varying national delineations, such as Canada's defining Arctic waters to cover those north of $60^{\circ} \mathrm{N}$ latitude. ${ }^{19}$ Another definition of the Arctic is provided by the Arctic Monitoring and Assessment Programme (AMAP), one of the Working Groups of the Arctic Council, ${ }^{20}$ under

\footnotetext{
${ }^{16}$ For details see R Churchill, 'The Exploitation and Management of Marine Resources in the Arctic: Law, Politics and the Environmental Challenge' in LC Jensen and G Hønneland (eds), Handbook of the Politics of the Arctic (Edward Elgar, Cheltenham, 2015) 147-184, at p. 156.

17 See Joint Communication of the European Commission and High Representative of the European Union for Foreign Affairs and Security Policy of 26 June 2012 on Developing a European Union Policy towards the Arctic Region: Progress since 2008 and Next Steps, JOIN (2012) 19, at p. 10; available at eeas.europa.eu/arctic_region/docs/join_2012_19.pdf; accessed 7 August 2017. Regrettably, the Joint Communication did not include more detailed data in this regard.

18 See inter alia C Cinelli, 'Law of the Sea, the European Union Arctic Policy and Corporate Ocean Responsibility' (2016) 30 Ocean Yearbook 242-266.

19 E Carina, H Keskitalo, T Koivurova, and N Bankes, 'Climate Governance in the Arctic: Introduction and Theoretical Framework' in T Koivurova, E Carina, H Keskitalo, and N Bankes (eds), Climate Governance in the Arctic (Springer, Berlin, 2009) 1-23, at p. 3.

20 The Arctic Council is a high-level intergovernmental forum for Arctic co-operation and not a formal international organisation; i.e., it has no legal personality and cannot generate legally binding obligations, but only issue recommendatory declarations. The Arctic Council lacks an express mandate for the conservation and management of Arctic fish stocks and its members are opposed to expanding the ambit of the Council to cover the matter. Thus it will not be considered in the ensuing analysis of fisheries enforcement. For the Arctic Council see at http://www.arcticcouncil.org/index.php/en/about-us; accessed 16 August 2017.
} 
which the boundary should lie between $60^{\circ} \mathrm{N}$ and the Arctic Circle, with some modification. ${ }^{21}$ Accordingly, the 'Arctic Ocean' includes the marine waters north of the Bering Strait, Greenland, Svalbard, and Franz Josef Land, excluding the Barents Sea. ${ }^{22}$

Although no possibility of fisheries within the central Arctic Ocean exists at present, commercial fishing activity does occur in the North Atlantic and North Pacific, and in some high seas areas ${ }^{23}$ in both oceans, such as in the 'Loophole' in the Barents Sea ${ }^{24}$ and the 'Donut Hole' in the central Bering Sea, ${ }^{25}$ and within the EEZ of the Arctic coastal States. However, as the Arctic is particularly intensely affected by climate change, fishing is likely to extend to new areas outside the EEZ of the States bordering the Arctic Ocean, following the northward migration of many valuable Arctic fish stocks, such as herring and cod, into the high seas. ${ }^{26}$

As recently reported with respect to fish stocks in the Central Arctic, [t]here are 12 species of fish in the current version of the FiSCAO [Fish Stocks in Central Arctic Ocean] database that have been sampled from locations that can be verified to lie in the High Seas area of the central Arctic Ocean. No invertebrates of potential commercial usage are currently present in the database from the High Seas area. Of the fish species sampled from the High Seas, three species are potentially of commercial interest, that is, listed in the United States FDA database of species that are or have been commercially marketed in the United States: Arctic cod

\footnotetext{
${ }^{21}$ See Arctic Monitoring and Assessment Program (AMAP), Arctic Pollution Issues: A state of the Arctic Environment Report (Oslo, 1997), 7.

${ }^{22}$ See Molenaar (n 1), at p. 431.

${ }^{23}$ There are four high seas pockets in the Arctic, namely the so-called 'Banana Hole' in the Norwegian Sea, the so-called 'Loophole' in the Barents Sea, the so-called 'Donut Hole' in the central Bering Sea and the Central Arctic Ocean; see Molenaar, ibid., at p. 432.

${ }^{24}$ See OS Stokke, 'The Loophole of the Barents Sea Fisheries Regime', in OS Stokke (ed), Governing High Seas Fisheries: The Interplay of Global and Regional Regimes (Oxford University Press, Oxford, 2001) 273-301.

${ }^{25}$ See Convention on the Conservation and Management of Pollock Resources in the Central Bering Sea (Washington, D.C., 16 June 1994, in force 8 December 1995) (1994) 34 ILM 67 (hereinafter: 'Donut Hole agreement').

${ }^{26} \mathrm{~L}$ Weidemann, International Governance of the Arctic Marine Environment (Springer, Berlin, 2014) 17.
} 
(Arctogadus glacialis), Polar cod (Boreogadus saida), and Greenland halibut (Reinhardtius hippoglossoides). ${ }^{27}$

However,

there are 339 species of fish and invertebrates in the current version of the FiSCAO database from the LMEs [Large Marine Ecosystems] surrounding the High Seas. The total number of species within the High Seas area is likely to increase as more information becomes available and as taxonomic status of species is further clarified. ${ }^{28}$

For example, according to the same Report, several commercial species in the Barents Sea are seen to expand their distribution northward, including pelagic fish species, such as mackerel, herring and blue whiting, and semi-pelagic fishes, such as beaked redfish (Sebastes mentella). ${ }^{29}$

Beyond the Central Arctic Ocean, reportedly, Arctic fisheries represent more than $10 \%$ of the global marine fish catch by weight and $5.3 \%$ of the crustacean catch. ${ }^{30}$ Currently, most Arctic fishing takes place in the Bering and Barents Seas, ${ }^{31}$ on the west coast of Greenland and around Iceland and the Faroe Islands. ${ }^{32}$

\section{The Applicable Legal Regime}

As to the legal regime applicable to Arctic fisheries, it is evident that international fisheries law, as part of the international law of the sea, applies to the Arctic Ocean, however defined. The cornerstone in the global jurisdictional framework is provided by the UN Convention on the Law of the Sea (LOSC), ${ }^{33}$ which sets out the division of seas and oceans in maritime zones and the basic rights and

${ }^{27}$ See Final Report of the Fourth Meeting of Scientific Experts on Fish Stocks in the Central Arctic Ocean (January 2017), 45; available at https://www.afsc.noaa.gov/Arctic_fish_stocks_fourth_meeting/pdfs/FourthFiSCAOreportfinalJan2 6_2017.pdf; accessed 16 August 2017.

${ }^{28}$ Ibid., p. 45.

${ }^{29}$ Ibid., p. 48.

30 J Christiansen \& JD Reist, 'Fishes' in Arctic Biodiversity Assessment. Status and Trends in Arctic Biodiversity (CAFF, Akureyri, Iceland, 2013).

${ }^{31}$ See Molenaar (n 1), at p. 433.

${ }^{32}$ See Weidemann (n 26), at p. 31.

${ }^{33}$ United Nations Convention on the Law of the Sea (Montego Bay, 10 December 1982, in force 16 November 1994) 1833 UNTS 396 (hereinafter: LOSC). 
obligations of States therein. All the common maritime zones are found in the Arctic, with the addition of a Fisheries Protection Zone (FPZ) established by Norway off Svalbard. ${ }^{34}$

The LOSC regulates the exercise of entitlements to fishing that States have as coastal or flag States, subject to various key obligations, including the obligation to adopt all necessary measures for the conservation and management of the living resources and to cooperate in relation to transboundary fish stocks. The provisions of the LOSC concerning fisheries are complemented by a wide range of global legally binding as well as non-legally binding fisheries instruments adopted by the United Nations Food and Agriculture Organization (FAO) and the United Nations General Assembly (UNGA); these instruments are also applicable in the marine Arctic. These include, in particular: the Fish Stocks Agreement; ${ }^{35}$ the 1993 Compliance Agreement; ${ }^{36}$ the Port State Measures Agreement; ${ }^{37}$ and among the non-binding instruments, the FAO Code of Conduct, ${ }^{38}$ and the International Guidelines on Deep-sea Fisheries in the High Seas, ${ }^{39}$ which have contributed to the phasing-out of large-scale pelagic driftnet fishing and imposed restrictions on bottom-fisheries on the high seas. ${ }^{40}$

It is true that the LOSC, the Fish Stocks Agreement and the FAO's fisheries instruments are primarily concerned with establishing the jurisdictional

\footnotetext{
${ }^{34}$ In a similar, yet not identical vein, Libya and Spain had established Fisheries Protection Zones in the Mediterranean Sea prior to transforming them to an EEZ in 2009 and 2013 respectively. For such 'sui generis' or minoris EEZ zones' see G Andreone and G Cataldi, 'Sui Generis Zones' in D Attard, M Fitzmaurice and NA Martinez Gutierez(eds), The IMLI Manual on International Maritime Law: The Law of the Sea, Vol I (Oxford University Press, Oxford, 2014) 217-238.

${ }^{35}$ Agreement for the Implementation of the Provisions of the United Nations Convention of the Law of the Sea of 10 December 1982, Relating to the Conservation and Management of Straddling Fish Stocks and Highly Migratory Fish Stocks (New York, 4 August 1995, in force 11 December 2011) (1995) 34(6) ILM 1542-1580. All the Arctic coastal States are parties to the Agreement (hereafter: Fish Stocks Agreement or FSA).

${ }^{36}$ FAO, Agreement to Promote Compliance with International Conservation and Management Measures by Fishing Vessels on the High Seas, (Rome, 24 November 1993, in force 24 April 2003) 2221 UNTS 91

37 Agreement on Port State Measures to Prevent, Deter and Eliminate Illegal, Unreported and Unregulated Fishing (Rome, 22 November 2009, in force 5 June 2016), Appendix E to FAO Doc. C 2009/REP, Report of the Conference of FAO[,] Thirty-sixth Session [,] Rome, 18-23 November 2009 (Rome: FAO, 2009).) (hereafter: Port States Measures Agreement or PSM Agreement).

${ }^{38}$ FAO, Code of Conduct for Responsible Fisheries, adopted at the $28^{\text {th }}$ Session of the FAO Conference, Rome, Italy, 31 October 1995. Available online at http://www.fao.org/docrep/005/v9878e/v9878e00.htm; accessed 16 August 2017.

392009 FAO International Guidelines on Deep-sea Fisheries in the High Seas, available at www.fao.org/ docrep/011/i0816t/i0816t00.htm; accessed 16 August 2017.

${ }^{40}$ See Liu and Kirk (n 4), at p. 269.
} 
framework, and they set out certain guiding principles in this regard, such as the precautionary approach. ${ }^{41}$ They do not contain, however, substantive fisheries standards or specific CMMs, such as catch restrictions through TACs [Total Allowable Catches], allocations of fishing opportunities through national quotas, gear restrictions, and temporal/seasonal and spatial measures (e.g., closed areas). Actual fisheries regulation is carried out by States individually or collectively, and the primary means for collective regulation is through RFMOs, which have the mandate to impose legally binding fisheries CMMs on their members. ${ }^{42}$

In the Arctic, a considerable number of regional, sub-regional and bilateral fisheries instruments and bodies apply to parts of the Arctic Ocean. ${ }^{43}$ However, the majority of the Arctic high seas, particularly the Central Arctic Ocean, is not covered by an RFMO or other arrangement managing species other than tuna or tuna-like species and anadromous species. The main exception is the North-East Atlantic Fisheries Commission (NEAFC), ${ }^{44}$ which has a mandate over the "European" wedge. In addition, other RFMOs have limited competence in the Arctic, especially for highly migratory and anadromous species, such as the International Commission for the Conservation of Atlantic Tuna (ICCAT), ${ }^{45}$ and

\footnotetext{
${ }^{41}$ See Article 6 of FSA.

${ }^{42}$ See Molenaar (n 1), at p. 435.

${ }^{43}$ See for more detail EJ Molenaar, 'Arctic Fisheries Management', in EJ Molenaar, AG Oude Elferink and DR Rothwell (eds), The Law of the Sea and the Polar Regions: Interactions between Global and Regional Regimes (Martinus Nijhoff Publishers, Leiden, 2013) 243-266, at pp. 248258 and L. Weidemann (n 26), at p. 192.

${ }^{44}$ See Convention on Future Multilateral Cooperation in the North-East Atlantic Fisheries (London, 18 November 1980; in force 17 March 1982) 1285 UNTS 129; as amended more recently on 11 August 2006 (Preamble, Arts. 1, 2 and 4) and on 11 August 2006 (in force 29 October 2013); available at www.neafc.org; accessed 7 August 2017. It replaced the earlier 1959 NorthEast Atlantic Fisheries Commission (486 UNTS 157), which in turn had replaced the 1946 Convention for the Regulation of Meshes and Fishing Nets and the Size Limits of Fish (231 UNTS 200). The earliest convention can be traced back to 1930s, when several conferences were held to address the issue of the rational exploitation of fish resources in the North-East Atlantic.

${ }^{45}$ The International Commission on the Conservation of Atlantic Tunas (ICCAT) is responsible for the conservation of tunas and tuna-like species in the Atlantic Ocean and adjacent seas. It was established by the International Convention for the Conservation of Atlantic Tunas (14 May 1966, in force 21 March 1969) 673 UNTS 63. All Arctic States are bound by this Convention - either as contracting parties or via the EU. Whether the Convention Area includes the marine Arctic, however, remains doubtful. The lack of an agreed northern limit to the Atlantic Ocean could imply the inclusion of Arctic waters in the spatial competence of ICCAT. Yet, the world map section used by ICCAT to illustrate the extent of the Convention area indicates that the northern limit of the Convention area is seen as $70^{\circ} \mathrm{N}$; available at http://www.iccat.int/en/convarea.htm; accessed 7 August 2017.
} 
the North Atlantic Salmon Conservation Organization (NASCO), ${ }^{46}$ as well as, arguably, the Northwest Atlantic Fisheries Organization (NAFO). ${ }^{47}$

The NEAFC has five members and five cooperating non-contracting parties (cooperating NCPs). Current members are Denmark (in respect of the Faroe Islands and Greenland), the EU, Iceland, Norway and the Russian Federation. The NEAF Convention applies to the areas of the Northeast Atlantic and Arctic Oceans, exclusive of the Baltic Sea and the Mediterranean Sea, as provided in the Convention. The term 'Convention Area' is defined in Article 1(a) of the NEAF Convention and comprises areas within national jurisdiction as well as areas beyond national jurisdiction. Pursuant to subparagraph (a)(1), the Convention Area covers a segment of the Arctic Ocean extending up to the geographical North Pole. The term 'Regulatory Area' is defined in Article 1(b) of the NEAFC Scheme of Control and Enforcement (NEAFC Scheme) as "the waters of the Convention Area, which lie beyond the waters under the fisheries jurisdiction of Contracting Parties". ${ }^{48}$ Thus, the 'Regulatory Area' includes not only the 'Banana Hole' and the 'Loophole', but also a part of the Central Arctic Ocean.

In short, fisheries management in the Loophole is a mixture of coastal State regulation and a multilateral approach. On the one hand, fisheries in the

\footnotetext{
${ }^{46}$ Convention for the Conservation of Salmon in the North Atlantic Ocean (2 March 1982, in force 1 October 1983), 1338 UNTS 33. The Convention is applicable to the salmon stocks that migrate beyond areas of fisheries jurisdiction of coastal States of the Atlantic Ocean north of $36^{\circ} \mathrm{N}$ latitude as part of their migratory range. NASCO has six Parties: Canada, Denmark (in respect of the Faroe Islands and Greenland), the EU, Norway, the Russian Federation and the US. See further information at: <http://www.nasco.int>. NASCO might be relevant also to Central Arctic Ocean, should the Atlantic salmon migrate in those waters.

47 See Convention on Future Multilateral Cooperation in the Northwest Atlantic Fisheries, (Ottawa, 24 October 1978, in force 1 January 1979), 1135 UNTS 369. NAFO has 12 Members from North America, Europe, Asia and the Caribbean. Of Arctic states, Canada, Iceland, Norway, Denmark (in respect of the Faroe Islands and Greenland), the Russian Federation and the USA are Members. In addition, the EU is a Member of the NAFO Convention, with the effect that Finland and Sweden are also bound by it. The NAFO Convention Area encompasses a large portion of the northwest Atlantic, including the 200-nautical-mile zones of the four coastal states of Canada, Denmark (Greenland), France (St. Pierre et Miquelon) and the USA. The regulatory area, however, is limited to the part of the NAFO Convention Area that is beyond coastal states' national jurisdiction and does not include any areas of the Arctic high seas; see at < https://www.nafo.int/Portals/0/PDFs/GeneralInfo/NAFO-map-poster-8.5x11-web.pdf>; accessed 7 August 2017. NAFO manages all fishery resources of the Convention Area, except for marine mammals, highly migratory species and sedentary species. See further information at www.nafo.int; accessed 7 August 2017.

${ }^{48}$ See the 2014 NEAFC Scheme of Control and Enforcement, as amended in 2015 and 2016, available at http://neafc.org/mcs/scheme; accessed 16 August 2017 (hereinafter NEAFC Scheme).
} 
Loophole are not excluded from NEAFC regulation, and the NEAFC has in fact adopted measures for some fisheries in this area. ${ }^{49}$ On the other hand, outside the framework of the NEAFC, the two coastal States (i.e., Norway and Russia) have managed to restrain fishing by distant water fishing nations, such as the EU, Greenland and the Faroe Islands, as well as Iceland, in the high seas part of the Barents Sea through the conclusion of access agreements to their EEZ, such as the Loophole Agreement. ${ }^{50}$ The NEAFC's Recommendations can apply to all or part of the 'Convention Area' or all or part of the much smaller 'Regulatory Area'. Of particular relevance for the purposes of this article is the detailed NEAFC Scheme, which also applies to the Central Arctic Ocean segment of the Regulatory Area.

The second more relevant regional fisheries commission, which, however, falls short of qualifying as an RFMO proper, ${ }^{51}$ is the Joint Commission established by the bilateral framework Agreement between Russia and Norway. ${ }^{52}$ This Agreement was adopted against the background of the failure to resolve the

${ }^{49}$ See Y Takei, Filling Regulatory Gaps in High Seas Fisheries (Martinus Nijhoff, Leiden, 2013)
163. For the 2017 CMMs of the Organisation see at https://www.neafc.org/managing_fisheries/measures/current; accessed 18 September 2017.

50 The conflict between the coastal states and Iceland was resolved in 1999 by a multilateral agreement among the three states concerned and two protocols between Iceland and each of the coastal states. See Agreement between the Government of Iceland, the Government of Norway and the Government of the Russian Federation Concerning Certain Aspects of Co-operation in the Area of Fisheries, (15 May 1999, in force 15 July 1999), (1999) 41 Law of the Sea Bulletin 53. See also the Protocol between the Government of Iceland and the Government of the Russian Federation under the Agreement between the Government of Iceland, the Government of Norway and the Government of the Russian Federation concerning Certain Aspects of Co-operation in the Area of Fisheries, (15 May 1999, in force 15 July 1999), reproduced in (1999) 14 International Journal of Marine and Coastal Law 488-490, and the Protocol between the Government of Norway and the Government of Iceland under the Agreement between the Government of Iceland, the Government of Norway and the Government of the Russian Federation concerning Certain Aspects of Co-operation in the Area of Fisheries, signed 15 May 1999, in force 15 July 1999, (1999) 41 Law of the Sea Bulletin 56. For the Loophole Agreement see also RR Churchill, 'The Barents Sea Loophole Agreement: A “Coastal State” Solution to a Straddling Stock Problem', (1999) 14(4) International Journal of Marine and Coastal Law 467-490, at pp. 468-475.

${ }^{51}$ The Joint Commission could be regarded as a Meeting of the Parties (MoP) or a Conference of the Parties (CoP), and thus, arguably, as a Regional Fisheries Management Arrangement (RFMA), in terms of Article 1(1)(d) of the Fish Stocks Agreement, which defines an RFMA as 'a cooperative mechanism established in accordance with the [LOS] Convention and this Agreement by two or more States for the purpose, inter alia, of establishing conservation and management measures in a subregion or region for one or more straddling fish stocks or highly migratory fish stocks'; see: n 35.

52 See Agreement between the Government of the Kingdom of Norway and the Government of the Union of Soviet Socialist Republics on Co-operation in the Fishing Industry (Moscow,11 April 1975, in force 11 April 1975) 983 UNTS 7. 
delimitation of the two States' maritime zones in the Barents Sea and was complemented by two other agreements, namely the Mutual Access Agreement ${ }^{53}$ and the Grey Zone Agreement. ${ }^{54}$ Whereas its Preamble refers to the North-East Atlantic Ocean, the Framework Agreement does not explicitly define its spatial scope. The Framework Agreement and thereby the mandate of the Joint Commission are therefore not exclusively confined to the maritime zones of the two States, and the mandate extends beyond the Barents Sea into the Norwegian Sea, the Greenland Sea and the Arctic Ocean. However, the cooperation is restricted to the stocks shared between the two States, such as cod, haddock and capelin, in line with Article 63(1) LOSC. This presumes that the stock is predominantly occurring within the EEZs of these two States, but may also include the regulation of their fishing activities in adjacent areas of the high seas (such as the Barents Sea Loophole). ${ }^{55}$

As a bilateral treaty arrangement, it is not opposable to third States in the region under international law (pacta tertiis nec nocent nec prosunt rule). ${ }^{56}$ As noted by Molenaar, 'it is considered to be unlikely that the Joint Commission will apply its unique Loophole practice also to some or all Central Arctic Ocean fisheries. The main reason for this is that it would have only limited effectiveness without the support of the other three Arctic Ocean coastal States' ${ }^{57}$ It is telling in this regard that in the Draft Agreement on Fisheries in Central Arctic Ocean, the participating States refer solely to the NEAFC as a competent fisheries management organization for part of the Central Arctic and not to the Joint Commission.

\section{The Draft Agreement on Fisheries in the Central Arctic Ocean}

\footnotetext{
53 Agreement between the Government of the Union of Soviet Socialist Republics and the Government of the Kingdom of Norway Concerning Mutual Relations in the Field of Fisheries, (Moscow, 15 October 1976, in force 21 April 1977) 1157 UNTS 146.

54 Agreement between Norway and the Soviet Union on provisional practical arrangements on fishing in an adjacent area of the Barents Sea of 11 January 1978 (Overenskomster med fremmede stater (1978), 436).

55 The author is indebted to the anonymous reviewer for this observation. On the functioning of the Joint Commission see Stokke (n 24), at p. 275 and Molenaar (n 1), at p. 438.

${ }^{56}$ See Article 34 of the 1969 Vienna Convention on the Law of Treaties (Vienna, 23 May 1969, in force 27 January 1980) 1155 UNTS 331 (hereinafter: VCLT).

${ }^{57}$ Molenaar (n 1), at p. 440.
} 
The regulatory gap concerning (future) fisheries in the Central Arctic Ocean, despite NEAFC's partial competence therein, has been of significant concern for the Arctic coastal States. In view of the uncertainty on the impacts of climate change in the Central Arctic and the lack of understanding of fish movement in the region, the Arctic States opted for establishing a moratorium on fishing in the region until concrete answers can be given to these questions. First was the United States that instituted a moratorium against commercial fisheries within their northern EEZ off the coast of Alaska. ${ }^{58}$ The US also led efforts to consider the possibility of extending this moratorium beyond their EEZ. To this end, there had been meetings between the five coastal States (Arctic Five) that led to a nonbinding Declaration, placing a moratorium on fishing in the region signed in Oslo on 16 July $2015 .{ }^{59}$ In essence, although recognizing that commercial fishing is not likely to occur soon in the region, it was noted that with the "dramatic reduction of the Arctic sea ice and other environmental changes in the Arctic", ${ }^{0}$ it was prudent to reach an agreement before fishing began. The five States agreed thus to allow their fishing vessels to operate in the region only once there are one or more international mechanisms to manage any such fisheries in 'accordance with international standards', ${ }^{61}$

Soon, however, the Arctic Five recognised the need to include the major international fishing nations in its negotiations on the future regime of the Central Arctic Ocean. Hence, they extended an invitation to Iceland, the EU, China, South Korea, and Japan (Arctic $5+5$ ). There have been five sets of meetings: 1-3 December 2015 and 19-21 April 2016, in Washington D.C.; 6-8 July 2016, in Iqaluit, Nunavut, Canada, 29 November-1 December 2016, in Tórshavn, the Faroe Islands; and 15-18 March 2017, in Reykjavik, Iceland. ${ }^{62}$ At the time of the

\footnotetext{
${ }^{58}$ U.S. National Oceanic and Atmospheric Administration, "Secretary of Commerce Gary Locke Approves Fisheries Plan for Arctic," (August 20, 2009), available at http://www.noaanews.noaa.gov/stories2009/20090820_arctic.html; accessed 16 September 2017. ${ }^{59}$ See: $\mathrm{n} 6$.

${ }^{60}$ U.S. Department of State, "Arctic Nations Sign Declaration to Prevent Unregulated Fishing in the Central Arctic Ocean," Press Release, Washington D.C. (July 16, 2015), available at https://2009-2017.state.gov/r/pa/prs/ps/2015/07/244969.htm; accessed 16 September 2017.

${ }^{61}$ See also R. Huebert, 'The Melting Ice and the Transforming Arctic Ocean' (2016) 31 Ocean Yearbook 57-79, at p. 66.

62 Chairman's Statement, Press Release, 'Meeting on High Seas Fisheries in the Central Arctic Ocean', Reykjavik, Iceland (15-18 March 2017).
} 
writing (December 2017), the Chairman, Mr David Bolton, has come up with a Compromise Text of Agreement that has been submitted to delegations for approval; ${ }^{63}$ however, as there has been no consensus on their part, there will be another meeting in the coming months to resolve any remaining issues.

In a nutshell, the Arctic $5+5$ believe that commercial fishing is unlikely to become viable in the high seas portion of the Central Arctic Ocean in the near future and, although recognising the partial competence of NEAFC therein, they do not find any need to establish an RFMO applicable to the whole (future) Agreement Area. Moreover, in keeping with the precautionary approach, they pledge to continue the moratorium on fishing on the high seas of Central Arctic until there is scientific evidence concerning sustainable fishing in the area. The particular objective of this legally binding agreement is:

to prevent unregulated fishing in the high seas portion of the central Arctic Ocean through the application of precautionary conservation and management measures as part of a long-term strategy to safeguard healthy marine ecosystems and to ensure the conservation and sustainable use of fish stocks. ${ }^{64}$

To this end, the parties agree to:

authorise vessels entitled to fly its flag to conduct commercial fishing in the Agreement Area only pursuant to:

a. conservation and management measures for the sustainable management of fish stocks which are adopted by one or more regional or subregional fisheries management organizations...or

b. interim conservation and management measures which may be adopted by the parties pursuant to Article $5 \ldots{ }^{65}$

On the other hand, the parties are encouraged to conduct scientific research and exploratory fishing in accordance with the measures established by the parties on the basis of the Agreement. There is specific reference to the Fish

\footnotetext{
${ }^{63}$ See Agreement to Prevent Unregulated High Seas Fisheries in the Central Arctic Ocean, Chairman's Compromise Proposal of 23 March 2017 (on file with the author).

${ }^{64}$ Draft Article 2, ibid.

${ }^{65}$ Draft Article 3 (1) -(3), ibid.
} 
Stocks Agreement with respect to straddling stocks. ${ }^{66}$ The Agreement provides for a review process every two years, in which, besides the review of all available scientific information developed through scientific research, parties will decide whether the distribution, migration and abundance of fish in the Agreement Area would support a sustainable commercial fishery and whether to commence negotiations to establish an RFMO in the region. ${ }^{67}$ As to third States, the Draft Agreement posits that 'the parties shall encourage non-parties to this Agreement to take measures that are consistent with the provisions of the Agreement'. ${ }^{68}$

When it comes to compliance and enforcement, which is the focus of the present article, the Draft Agreement sets out, first, that 'the Parties shall ensure compliance with the interim measures established by this Article [Article 3], and with any additional or different interim measures that may be established pursuant to Article 5, paragraph 1 (c) ${ }^{6} .{ }^{69}$ Second, as for third States, 'the parties shall take measures consistent with international law to deter the activities of vessels entitled to fly the flags of non-parties that undermine the effective implementation of this Agreement'. ${ }^{70}$

It readily appears that the delegations do not purport to set out any detailed enforcement scheme and they confine themselves to the 'measures consistent with international law': the parties to the Agreement are responsible to ensure that the vessels flying their flag would abide by the provisions of the Agreement and, vaguely, to take measures consistent with international law to deter activities by third States that undermine the implementation of the Agreement. Thus everything boils down to the simple, yet difficult question: what measures vis-àvis third States would be 'consistent with international law' in this respect?

Addressing this question is the focus of the remaining part of this article. The analysis is informed by the applicable treaties, including the LOSC, the Fish Stocks Agreement and the Port States Measures Agreement, binding on the

\footnotetext{
${ }^{66}$ Draft Article 3 (6), ibid.

${ }^{67}$ Draft Article 5 (1) (c), ibid.

${ }^{68}$ Draft Article 8 (1), ibid.

${ }^{69}$ Draft Article 3 (5), ibid.

${ }^{70}$ Draft Article 8 (2), ibid.
} 
majority of the Arctic $5+5,{ }^{71}$ as well as by the NEAFC Scheme, which, in the absence of a bespoke RFMO, is applicable to a certain portion of the Arctic Ocean. Of relevance also are the EU regulations, because the EU is both a Member of the NEAFC and a negotiating party to the new agreement. As stated in the Introduction, it is impossible within the spatial confines of this article to thoroughly scrutinise all possible enforcement tools in this regard; rather, the focus is on those that appear most likely to be effective to address current and future IUU fishing in high seas areas of the Arctic Ocean.

\section{Enforcement Tools for Arctic High Seas Fisheries}

\section{Port State Control}

It is widely acknowledged that the best means to address IUU fishing, as well as other illicit activities, on the high seas is port State control. On the high seas vessels are subject to the exclusive jurisdiction of their flag States pursuant to Article 92 LOSC; when at port they fall under the plenary jurisdiction of the coastal State. ${ }^{72}$ In fact, port State control has already a well-established track record in the area of merchant shipping, and has had a very significant positive impact on the problem of substandard shipping. ${ }^{73}$ Port State regimes are generally intended to ensure mandatory inspection of vessels when they enter ports. In

\footnotetext{
${ }^{71}$ Particularly, among the Arctic States: i) the Russian Federation is party to the LOSC, Fish Stocks Agreement and a contracting party to NEAFC, but not to the PSM Agreement ; ii) Canada is party to the LOSC and the Fish Stocks Agreement, but has not ratified the PSM Agreement and is only a cooperating non-contracting party to the NEAFC; iii) Norway is party to all agreements and a contracting party to NEAFC; iv) Denmark is party to the LOSC, the Fish Stocks Agreement and the NEAFC, but not to the PSM Agreement; and v) the USA is party only to the Fish Stocks Agreement. On the other hand, among the Plus Five: i) the EU is party to all agreements, including the NEAFC; ii) Japan is party to all agreements except the NEAFC; iii) Iceland is party to the LOSC, the PSM Agreement, the NEAFC, but not to the Fish Stocks Agreement, iv) the Republic of Korea is party to all agreements except the NEAFC and finally v) China is party only to the LOSC.

${ }^{72}$ Nevertheless, the coastal State usually refrains from exercising criminal jurisdiction over matters involving solely the internal discipline of the ship. See, inter alia, A Clapham, Brierly's Law of Nations, ( $7^{\text {th }}$ ed., Oxford University Press, Oxford, 2012) 215.

${ }^{73}$ See, inter alia, T McDorman, 'Port State Enforcement: A Comment on Article 218 of the 1982 Law of the Sea Convention' (1997) 28 Journal of Maritime Law \& Commerce 305-322; RR Churchill, 'Port State Jurisdiction Relating to the Safety of Shipping and Pollution from Ships What Degree of Extra-territoriality?' (2016) 31(3) International Journal of Marine \& Coastal Law 442-469.
} 
recent years, there has been increased interest in the possibility of applying similar regimes to internationally or regionally agreed standards for fisheries. Indeed, as a result of the inability or unwillingness of many flag States to control effectively the fishing operations carried out by vessels flying their flag, the burden of combatting overfishing has shifted to a considerable degree onto port States. With the 2009 Port State Measures Agreement (PSM Agreement) having just entered into force ${ }^{74}$ port State control appears to be at the forefront of the fight against IUU fishing and is of considerable relevance to Arctic fisheries.

The LOSC falls short of providing for the exercise of jurisdiction over foreign vessels in ports for violations on the high seas of fisheries regulations. It does so in Article 218 only with respect to pollution violations on the high seas, which is sometimes assumed, on the expression unius est exclusio alterius principle, to indicate that no similar power exists for fisheries. But this is misconceived, because Article 218 simply makes it possible for port States to do pursuant to a treaty what they could formerly do under the customary international law rules of jurisdiction. ${ }^{75}$ Indeed, there is no doubt that the port State can enforce not only its own national laws but also its international obligations on foreign fishing vessels in its ports, including the landing, selling, and even transportation of fish caught illegally on the high seas (residual port-State jurisdiction). This was supported by both the 1993 Compliance Agreement ${ }^{76}$ and was also expressly acknowledged in the Fish Stocks Agreement ${ }^{77}$ and the more recent PSM Agreement.

In the Fish Stocks Agreement, Article 23 sets out that the port State 'has the right and the duty to take measures, in accordance with international law, to promote the effectiveness of subregional, regional and global conservation and

\footnotetext{
74 The Port States Measures Agreement entered into force on 5 June 2016, and as at 18 October 2017, 51 FAO Members, including the EU, had become parties. A current status of the Agreement is available at http://www.fao.org/fishery/psm/agreement/parties/en; accessed 18 December 2017. As reported also above, among the Arctic coastal States only Norway and US are parties at the time of the writing; among the Member States of NEAFC, besides Norway and the EU, Iceland is also party to the Agreement.

75 See A Serdy, 'The Shaky Foundations of the FAO Port State Measures Agreement: How Watertight Is the Legal Seal against Access for Foreign Fishing Vessels?' (2016) 31(3) International Journal of Marine and Coastal Law 422-441, at p. 425.

${ }^{76}$ See $\mathrm{n} 36$.

77 'Nothing in this article affects the exercise by States of their sovereignty over ports in their territory in accordance with international law'; see Article 23 (4) Fish Stocks Agreement.
} 
management measures'; ${ }^{78}$ thus, a port State may, inter alia, inspect documents, fishing gear and catch on board fishing vessels, when such vessels are voluntarily in its ports or at its offshore terminals. ${ }^{79}$ Additionally,

States may adopt regulations empowering the relevant national authorities to prohibit landings and transshipments where it has been established that the catch has been taken in a manner which undermines the effectiveness of subregional, regional or global conservation and management measures on the high seas. ${ }^{80}$

In our case, such measures could be those under the NEAFC or, arguably, the ICCAT with respect to tuna, which is a highly migratory species. ${ }^{81}$ The effectiveness of the Fish Stocks Agreement is, arguably, undermined by the lack of any provision about direct enforcement (punitive) measures related to the activities on the high seas. ${ }^{82}$

The PSM Agreement marks a significant step forward in ensuring 'the long-term conservation and sustainable use of living marine resources and marine ecosystems', ${ }^{83}$ by setting out minimum standards for port State measures that the contracting States shall adopt. At the same time it recognizes

the exercise by parties of their sovereignty over ports in their territory in accordance with international law, including their right to deny entry thereto as well as to adopt more stringent port State measures than those provided for in this agreement, including such measures adopted pursuant to a decision of a regional fisheries management organisation. ${ }^{84}$

Accordingly, a party is at liberty to take additional measures, as long as they are in conformity with international law.

\footnotetext{
${ }^{78}$ Article 23 (1), ibid. (emphasis added).

${ }^{79}$ Article 23 (2), ibid.

${ }^{80}$ Article 23 (3), ibid.

${ }^{81}$ See LOSC, Annex I.

82 See EJ Molenaar, 'Port State Jurisdiction to Combat IUU Fishing: The Port State Measures Agreement', in DA Russell and DL Vander Zwaag (eds), Recasting Transboundary Fisheries Management Arrangements in Light of Sustainability Principles (Martinus Nijhoff, Leiden, 2010) 369-386, at p. 386

${ }^{83}$ See Article 2 PSM Agreement. See also recent post at EJILTALK commenting on the PSM Agreement, https://www.ejiltalk.org/first-global-treaty-against-illegal-unreported-and-unregulatediuu-fishing-enters-into-force/ (June 9, 2017); accessed 12 June 2017.

${ }^{84}$ See Article 4(1)(b) and also Article 18(3) PSM Agreement.
} 
As regards the Arctic, the NEAFC Scheme makes reference to the Agreement as a minimum standard for port State control of foreign fishing vessels and non-Contracting Party vessels. It requires Contracting Parties to cooperate in its effective implementation of the PSM Agreement and will take effect when all NEAFC Contracting Parties become party to the latter Agreement, ${ }^{85}$ which has not occurred at the time of writing. ${ }^{86}$

As to the concrete measures that States parties to the PSM Agreement - in the Arctic, Norway and the US - may take, which to a certain extent coincide with those under the NEAFC Scheme - for Iceland and the EU Member States - ${ }^{87}$ these may be summarized as follows:

- Advance Notice of Port Entry: The PSM Agreement requires fishing vessels and vessels involved in fishing-related activities to provide a reasonable advance notice of their entry into port, a copy of their authorisations to fish, details of their fishing trip and quantities of fish on board. ${ }^{88}$ This is in line with Article 25 (2) LOSC that implies the right of coastal States to prescribe conditions for the admission of foreign vessels to its ports.

- Inspection of Fishing Vessels: a port State is required to carry out inspections of foreign fishing vessels for the purpose of monitoring compliance with relevant conservation and management measures. The parties are also required to seek the minimum levels for inspection of vessels through RFMOs. For example, in the context of the NEAFC, 'each Contracting Party shall carry out inspections

\footnotetext{
${ }^{85}$ See Articles 20bis and 38bis of the NEAFC Scheme. The application of the FAO Agreement is without prejudice to additional specified provisions in the Scheme.

${ }^{86}$ See $\mathrm{n} 74$.

${ }^{87}$ For EU Member States, the applicable legislation is set out in COUNCIL REGULATION (EC) No. 1005/2008 of 29 September 2008 establishing a Community system to prevent, deter and eliminate illegal, unreported and unregulated fishing, amending Regulations (EEC) No 2847/93, (EC) No. 1936/2001 and (EC) No. 601/2004 and repealing Regulations (EC) No. 1093/94 and (EC) No. 1447/1999. Official Journal of the EU L 286/1 (29.10.2008) (hereinafter: EU IUU Regulation). On the Regulation, see M. Tsamenyi, MA Palma, B Milligan and K Mfodwo, 'The European Council Regulation on IUU Fishing: An International Fisheries Law Perspective' (2010) 25(1) International Journal of Marine and Coastal Law 5-31.

${ }^{88}$ See Article 8 PSM Agreement.
} 
of at least $15 \%$ of landings or transhipments in its ports during each reporting year.' 89

If there are reasonable grounds to believe that the vessel has engaged in or supported IUU fishing, the port State may undertake several measures, including: notifying the flag State and, as appropriate, relevant coastal States, RFMOs and other international organizations; and denying the vessel the use of its port for landing, transshipping, packaging and processing of fish, etc. ${ }^{90}$ that have not been previously landed and for other port services, including, inter alia, refueling and resupplying, maintenance and drydocking, if these actions have not already been taken in respect of the vessel, in a manner consistent with this Agreement, including Article 4. The prohibition on landing and transshipment of fish is the most common PSM undertaken against third-State vessels which have undermined international and regional CMMs. It may also be considered as one of the most effective measures in deterring IUU fishing, because a restriction of this nature directly affects the marketing or trade of fish. ${ }^{91}$ Such measures have been taken up by the NEAFC, ${ }^{92}$ as well as by the EU. ${ }^{93}$

Besides denial of entry and facilities, some RFMOs have indicated that States may criminalize activities taking place in the port (such as landing, transshipment, or even possession of fish) due to the violation of conservation measures on the high seas. ${ }^{94}$ The jurisdictional basis for this criminalization is found in the territoriality principle, because the activity that is criminalized per se takes place at the port, i.e., in the territory of the respective State. ${ }^{95}$ In the Arctic context, Norwegian legislation, for example, provides for criminal penalties,

\footnotetext{
${ }^{89}$ Article 25 (1) NEAFC Scheme.

${ }^{90}$ See Article 18 PSM Agreement.

91 See MA Palma, M Tsamenyi and W Edeson, Promoting Sustainable Fisheries: The International Legal and Policy Framework to Combat Illegal, Unreported and Unregulated Fishing (Martinus Nijhoff Publishers, Leiden, 2010) 167.

92 See Articles 28-33 NEAFC Scheme.

93 According to Article 11 (2) of the EU IUU Regulation, 'if the results of the inspection provide evidence that a third country fishing vessel has engaged in IUU fishing in accordance with the criteria set out in Article 3, the competent authority of the port Member State shall not authorise such vessels to land or transship their catch'.

94 See S. Kopela, Port-State Jurisdiction, Extraterritoriality, and the Protection of Global Commons, (2016) 47 Ocean Development \& International Law 89-130, at p. 99 and further references under $\mathrm{n} 114$.

95 On territoriality as head of jurisdiction see M Gavouneli, Functional Jurisdiction in the Law of the Sea (Martinus Nijhoff Publishers, Leiden, 2007) 7.
} 
along with administrative fines. According to the 2009 Marine Resources Act, which replaced the 1983 Sea Water Fisheries Act,

serious offences committed through gross negligence or wilfully are punishable by a term of imprisonment not exceeding three years. In evaluating whether an offence is serious, special weight shall be given to whether the financial or potential financial gain from the offence was large, whether the offence was committed systematically and over time, and whether it was committed as part of an organised activity. ${ }^{96}$

Interestingly, however, the Act states that

if a foreign vessel has contravened [the relevant] provisions ... outside the territorial sea, a term of imprisonment may not be imposed ... A term of imprisonment may nevertheless be imposed if this follows from an agreement with a foreign state or if the vessel is stateless. ${ }^{97}$

As far as foreign-flagged vessels having contravened regulations in the EEZ are concerned, this seems to be in line with Article 73 (3) LOSC, which states:

(c)oastal State penalties for violations of fisheries laws and regulations in the exclusive economic zone may not include imprisonment, in the absence of agreements to the contrary by the States concerned, or any other form of corporal punishment.

However, in respect of stateless vessels that have contravened the relevant regulations on the high seas, this legislation is a form of extraterritorial jurisdiction: it is based most probably either on the 'objective territoriality' principle, ${ }^{98}$ if the fishing vessel concerned purported to land the fish stocks at Norwegian ports, or on the principle of universality, ${ }^{99}$ if there is no other

96 See Marine Resources Act (17.03.2015), Section 64; available at <https://www.fiskeridir.no/English/Fisheries/Regulations/The-marine-resources-act>; accessed 27 July 2017.

${ }^{97}$ Ibid.

98 See M Akehurst, 'Jurisdiction in International Law' (1972-73) 46 British Yearbook of International Law 145-257, at pp. 152-3.

${ }^{99}$ See L Rydams, Universal Jurisdiction: International and Municipal Legal Perspectives (Oxford University Press, Oxford, 2003). 
jurisdictional nexus with Norway. This author has argued elsewhere ${ }^{100}$ that statelessness per se does not suffice to extend coastal State jurisdiction over stateless vessels on the high seas; thus the jurisdictional basis is to be found in one of the abovementioned principles.

\section{Denial of Entry to or Use of Ports}

The PSM Agreement envisages denial of use of ports at three separate points in time: prior to entry into port, upon entry into port and after inspection:

i) prior to entry into port, denial of the use of the port is required if a vessel is on an IUU Vessel List of an RFMO (unless other appropriate actions are taken); ${ }^{101}$

ii) where a vessel has entered port, ${ }^{102}$ and

iii) after inspection, States must deny the use of a port where there are clear grounds for believing that a vessel has engaged in IUU fishing or fishing-related activities. $^{103}$

Denial of entry into ports is very often the case in relation to the fishing vessels flying the flag of a non-contracting party. For example, under the NEAFC Scheme,

Masters of non-Contracting Party vessels intending to call into a port shall notify the competent authorities of the port state in accordance with the provisions of Article 22....The port state shall prohibit the entry into its ports of vessels that have not given the required prior notice of landing or provided the information referred to in paragraph $\mathrm{I}^{104}$

As welcome as port State control schemes may be, there have been voices of criticism in respect of either the legality of certain measures or their efficacy. Apparently, the success of port State control depends on how many States share the same obligations. ${ }^{105}$ In addition, measures such as denial of entry into ports

\footnotetext{
${ }^{100}$ See E Papastavridis, 'Enforcement Jurisdiction in the Mediterranean Sea: Illicit Activities and the Rule of Law on the High Seas' (2010) 25(4) The International Journal of Marine and Coastal Law 569-599, at pp. 582-586.

${ }^{101}$ Article 9(4) and (5) PSM Agreement.

${ }^{102}$ Article 11, ibid.

103 Article 18, ibid.

104 Article 39, NEAFC Scheme.

${ }^{105}$ See comments by Serdy (n 75), at p. 428.
} 
should be taken with a pinch of salt in light of potential conflicting treaty provisions, for example under international trade regimes. The elephant in the room is the multilateral General Agreement on Tariffs and Trade (GATT). ${ }^{106}$ Twice in recent years this instrument has been invoked to challenge the closure of ports by one State or group of States to fishing vessels of another State or group of States in the course of a wider fisheries dispute; however, both cases were settled between the parties. ${ }^{107}$

In concluding, PSM may prove to be a very effective tool for enforcement purposes in the Arctic. For the NEAFC Members, including the EU, there is already a comprehensive and robust port control scheme in place; for other Arctic States parties to the PSM Agreement, such as Norway, the US and Iceland, similar obligations are included therein. The EU had already established, even prior to ratifying the PSM Agreement, an enhanced port-control mechanism. Evidently port State control by EU Member States attains even greater prominence in view of the volume of Arctic fisheries that, reportedly, are landed and sold on the EU market. $^{108}$

\section{Enhancing Flag State Duties and Enforcement}

Given that only the flag State may exercise jurisdiction over its (fishing) vessels on the high seas, it is in the best interest of all States concerned and the international community to facilitate this exercise of jurisdiction. Indeed, in view of the gaps in the implementation and enforcement of flag State duties, including

\footnotetext{
106 The GATT, though not drafted as a treaty in its own right in its original form, nonetheless indirectly gained that status through the Protocol of Provisional Application of the General Agreement on Tariffs and Trade (Geneva, 30 October 1947, in force 1 January 1948), 55 UNTS 308. Since 1995 the GATT has been maintained in force among Members of the World Trade Organization pursuant to the Agreement Establishing the World Trade Organization (Marrakesh, 15 April 1994, in force 1 January 1995), 1867 UNTS 3, Article II (2) and (4).

107 See WTO Doc. WT/DS193/3 (6 April 2001), Chile - Measures Affecting the Transit and Importation of Swordfish: Arrangement between the European Communities and Chile and WTO Doc. WT/DS469/2 (10 January 2014), European Union - Measures on Atlanto-Scandian Herring: Request for the Establishment of a Panel by Denmark in Respect of the Faroe Islands. For commentary see MA Orellana, 'The Swordfish Dispute between the EU and Chile at the ITLOS and the WTO' (2002) 71 Nordic Journal of International Law 55-81.

${ }^{108}$ See $\mathrm{n} 23$.
} 
in respect of fisheries conservation and management measures, ${ }^{109}$ the international community has consistently tried to improve flag State duties in this regard. Suffice it to mention Article 117 LOSC which provides for the duty of high seas fishing states to take conservation measures for their nationals as elaborated in Article 119(1) LOSC, as well as in various provisions under the 1993 Compliance Agreement and the Fish Stocks Agreement. According to these instruments, the flag State shall take such measures as may be necessary to ensure that fishing vessels entitled to fly its flag do not engage in any activity that undermines the effectiveness of CMM. ${ }^{110}$ By referring to CMM, the instruments in question refer to these measures that are adopted by global or regional fisheries bodies of which the flag State is either a contracting party or a cooperating non-contracting party. ${ }^{111}$ In fact, provisions on flag State duties have also been incorporated into CMM adopted by existing RFMOs, including the NEAFC in the Arctic, ${ }^{112}$ as well as in EU legislation (EU IUU Regulation). ${ }^{113}$

As to the specific measures that are employed in this regard, reference could be made to the following: first, proper identification of the fishing vessels through registration and licensing; second, cooperation with the flag State in raising awareness of IUU fishing incidents; and third, listing of vessels engaged in such incidents and revoking their licenses or taking measures against the flag States themselves in cases of non-cooperation. None of these measures involves enforcement by third States per se. However, they do significantly enhance the

\footnotetext{
${ }^{109}$ For extensive discussion of the failure of flag State obligation in relation to fisheries see $\mathrm{R}$ Rayfuse, Non-Flag State Enforcement in High Seas Fisheries (Martinus Nijhoff Publishers, Leiden, 2004) Chapter 1.

${ }^{110}$ Under, e.g., Article III of the FAO Compliance Agreement, the flag state, even if it granted an exemption for fishing vessels of less than 24 metres in length from the application of other provisions of the Agreement in accordance with Art. II(2), shall: 'take measures as may be necessary to ensure that fishing vessels entitled to fly its flag do not engage in any activity that undermines the effectiveness of international conservation and management measures'. See also Article 18 (1) Fish Stocks Agreement.

${ }^{111}$ According to Article I (b) of the FAO Compliance Agreement, 'international conservation and management measures" means measures to conserve or manage one or more species of living marine resources that are adopted and applied in accordance with the relevant rules of international law as reflected in the 1982 United Nations Convention on the Law of the Sea. Such measures may be adopted either by global, regional or subregional fisheries organizations, subject to the rights and obligations of their members, or by treaties or other international agreements'.

${ }^{112}$ See, e.g., Article 4 of the 2014 NEAFC Scheme.

${ }^{113}$ See, inter alia, Articles 20 and 37 of the EU IUU Regulation.
} 
duties of the flag State concerning its vessels and hence facilitate the enforcement by the latter State itself.

\section{Vessel Registration, Recording and Authorization to Fish}

Under international law, it falls upon flag States to fix the conditions for the grant of its nationality to ships, for the registration of ships in its territory, and for the right to fly its flag. Besides the inchoate provision of Article 91(1) LOSC concerning the 'genuine link between the State and the ship', the LOSC does not elaborate on the conditions that may be imposed by flag States to register vessels, including fishing vessels. ${ }^{114}$ More importantly, it needs to be underscored that in light of the wording of Article 91 (1) LOSC, vessels may hold nationality independent of registration. For example, 'national legal systems commonly only require vessels of certain size to register, and smaller vessels may be entitled to fly the flag of their owner state's nationality without registration'.115 Consequently, by virtue of the LOSC, the flag State is under no obligation to register its fishing vessels.

Nevertheless, various FAO instruments evidently entail registration and specific documentation. According to the FAO Code of Conduct and the FAO Technical Guidelines, a flag State needs to ensure that vessels to which it has allocated its flag carry onboard the original Certificate of Registry or a document that would attest to the nationality of the fishing vessels. ${ }^{116}$ These guidelines are not binding per se; yet certain measures, such as Certificates of Registry, may become mandatory pursuant to a treaty or under an RFMO. In particular, the Fish Stocks Agreement ${ }^{117}$ and the FAO Compliance Agreement ${ }^{118}$ set forth the duty of the flag State to establish requirements for the marking of fishing vessels in accordance with the FAO Standard Specifications for the Marking and

\footnotetext{
${ }^{114}$ Under Article 91 LOSC: 'every State shall fix the conditions for the grant of its nationality to ships, for the registration of ships in its territory, and for the right to fly its flag'. See also in this regard H Meyers, The Nationality of Ships (Sijthoff, The Hague, 1967)

${ }^{115}$ D Guilfoyle, Shipping Interdiction and the Law of the Sea (Cambridge University Press, Cambridge, 2009) 95.

116 FAO, Code of Conduct for Responsible Fisheries, para. 8.2.2. See also FAO, 'Fishing Operations,' FAO Technical Guidelines for Responsible Fisheries No. 1 (FAO, Rome, 1996), at para. 26.

${ }_{117}$ Article 18 (3) (d) Fish Stocks Agreement.

${ }^{118}$ Article III (6) of the Compliance Agreement.
} 
Identification of Fishing Vessels. ${ }^{119}$ This duty usually applies to fishing vessels more than 24 meters in length, ${ }^{120}$ unless provided otherwise in national legislation. $^{121}$

The problem, however, remains with respect to the fishing vessels of States non-parties to treaties like the Fish Stocks Agreement or Non-Members of RFMOs, like the NEAFC: it still rests upon the flag State to provide for the registration of fishing vessels. Certainly, the duty to register fishing vessels is the first requisite step to this end. To this we should add measures, such as authorization to fish and a global record of vessels, which would allow better awareness of fishing activities and facilitate the enforcement of fishing laws and regulations, primarily by the flag States concerned.

Indeed, another measure linked to the registration of vessels ${ }^{122}$ is the issuance of licenses or authorisations to fish. In the Arctic context, Article 4 (1) (b) of the NEAFC sets forth that the parties shall ensure that only authorised fishing vessels flying its flag conduct fishing activities. To this end,

each Contracting Party shall notify, in computer readable form, to the Secretary prior to 1 January of each year if possible, or in any case before the vessel's entry into the Regulatory Area, all fishing vessels authorised to fish and notably whether the vessel is authorised to fish one or more regulated resource. ${ }^{123}$

\section{Cooperation and Sanctions}

In the case of a violation of the applicable CMM on the Arctic high seas, there must be a certain level of cooperation between the coastal States in the region, the competent RFMO, in casu the NEAFC, and the flag State of the 'suspected fishing vessel'. Indeed, as the NEAFC Scheme provides, 'surveillance [on the high seas] shall be based on sightings of fishing vessels by assigned inspectors

\footnotetext{
${ }^{119}$ FAO, The Standard Specifications for the Marking and Identification of Fishing Vessels (FAO, Rome, 1989).

${ }^{120}$ Cf. Article II (2) FAO Compliance Agreement.

${ }^{121}$ See also Article 6 of NEAFC Scheme.

122 The IPOA-IUU provides the link between the two measures, in that flag States would need to consider conducting the separate functions of registration and licensing of fishing vessels in a manner that ensures each gives appropriate consideration to the other; see para 40.

${ }^{123}$ Article 5 of the NEAFC Scheme.
} 
from an inspection vessel or aircraft assigned to the Scheme'. ${ }^{124}$ Thus, at least for Member States, any surveillance practice involves the reporting to both the Member flag State and the competent RFMO. As per the follow-up measures to be made, the NEAFC prescribes that

the appropriate authorities of a Contracting Party notified of an infringement committed by a fishing vessel of that Party shall take prompt action to receive and consider the evidence of the infringement and, conduct any further investigation necessary for the follow up to the infringement and, whenever possible, inspect the fishing vessel concerned. ${ }^{125}$

This is certainly a due diligence obligation of the flag State to carry out.

As to vessels of third States involved in IUU fishing on the high seas, arguably the most powerful tool is the recoding of these vessels and a notification procedure, i.e., from the RFMO, e.g., the NEAFC and its Members to the flag State concerned. ${ }^{126}$ Under the NEAFC, when transmitting such information to the flag State concerned, the NEAFC Secretary shall 'request that it take measures in accordance with its applicable legislation to ensure that the vessel or vessels in question desist from any activities that undermine the effectiveness of NEAFC Recommendations...' ${ }^{127}$ In any case, the Secretary is responsible for placing all vessels of third States that are presumed to be engaged in IUU fishing on IUU fishing lists, ${ }^{128}$ unless these States obtain the status of a cooperating NCP. ${ }^{129}$

As an additional measure vis-à-vis the flag State, Article 46 (3) of the Scheme states that

'the Contracting parties may co-operate to adopt appropriate multilaterally agreed non-discriminatory trade related measures, consistent with the World Trade Organisation (WTO), that may be

\footnotetext{
${ }^{124}$ Article 17 of NEAFC Scheme.

125 Article 28 (4), ibid.

${ }^{126}$ See Article 37 (1), ibid., with respect to the NEAFC.

127 Article 42 (2), ibid.

${ }^{128}$ See Articles 44-46, ibid.

${ }^{129}$ See Articles 34-36, ibid.
} 
necessary to prevent, deter, and eliminate the IUU fishing activities identified by the Commission'.

Where these measures do not constitute a breach of an international obligation owed to the State concerned, then this is a form of retorsion, i.e., an unfriendly act that States often take to put pressure against another State. ${ }^{130}$ If, however, such measures involve the breach of an international obligation owed to the flag State other than WTO law, as explicitly stated -, then they qualify as countermeasures under international law and will be subject to conditions, like proportionality, prior notification, etc. ${ }^{131}$

In addition to measures under the NEAFC Scheme, the EU may play a significant role in this regard. The 2008 IUU Regulation provides for a Community IUU Vessel List, including both vessels flying the flag of Member States, if the latter do not take the requisite measures, and third-State vessels, which are engaged in IUU fishing. ${ }^{132}$ According to the definition provided by the EU IUU Regulation, 'unregulated fishing' includes:

fishing activities:(a) conducted in the area of application of a relevant regional fisheries management organisation by fishing vessels without nationality, by fishing vessels flying the flag of a State not party to that organisation or by any other fishing entity, in a manner that is not consistent with or contravenes the conservation and management measures of that organisation; or (b) conducted in areas or for fish stocks in relation to which there are no applicable conservation or management measures by fishing vessels in a manner that is not consistent with State responsibilities for the conservation of living marine resources under international law.

\footnotetext{
${ }^{130}$ Measures of retorsion amount to unfriendly act(s), i.e., acts which are wrongful not in the legal but only in the political or moral sense, or a simple discourtesy; see T Giegerich, 'Retorsion' in Max Planck Encyclopaedia of Public International Law (March 2011); available at http://opil.ouplaw.com/view/10.1093/law:epil/9780199231690/law-9780199231690-e983; accessed 30 July 2017.

${ }^{131}$ See Articles 22 and 49-54 of the ILC Articles on Responsibility of States for Internationally Wrongful Acts, UN General Assembly Official Records, $56^{\text {th }}$ Session, Supp. No. 10 at UN Doc $\mathrm{A} / 56 / 10$, at 31 .

${ }^{132}$ See Articles 26-29 EU IUU Regulation.
} 
Subsequently, it covers vessels engaged in fishing activities in contravention of conservation measures adopted by the NEAFC in the Regulatory Area or in contravention of the laws and regulations governing high seas fisheries in high seas areas of the Arctic outside the Regulatory Area of the NEAFC. Thus, these vessels may be duly recorded, following up the procedures of the EU IUU Regulation. Interestingly, this Community List would also include IUU vessel lists adopted by RFMOs; ${ }^{133}$ as is set out, 'the Commission shall publish the Community IUU vessel list in the Official Journal of the European Union and shall take any measure necessary to ensure its publicity, including by placing it on its website.' ${ }^{134}$ Last, a series of sanctions are provided for non-cooperating flag States. ${ }^{135}$

Inclusion in the IUU vessel lists of the EU and RFMOs, notification of the flag State, and imposition of measures, in the form of retorsion, against the persistent delinquent flag State, are among those that States may take against IUU vessels fishing in parts of the high seas of the Arctic not covered by the NEAFC.

In concluding, it is submitted that enforcement by the flag State for activities, in casu fishing activities in the Arctic high seas, remains the rule and not the exception. To enhance such enforcement, it is necessary to enhance the duty of the flag State to control the vessels flying its flag and enforce the applicable international laws and regulations. Tools that may be employed to this end include, inter alia, the following: the registration of the fishing vessels and their licensing to fish; cooperation between flag States and the competent RFMOs; the listing of vessels that are engaged in IUU fishing and the corresponding sanctions. In this regard, the EU is well placed to assist in such enforcement procedures.

\section{Inspections at Sea}

Besides enforcement by the port State or the flag State itself, it is questioned whether international law of the sea permits enforcement by third States in cases of IUU fishing on the high seas, which may also find application on the high seas

\footnotetext{
${ }^{133}$ See Article 30, ibid.

${ }^{134}$ Article 29 (2), ibid.

${ }^{135}$ See EU IUU Regulation, Chapter VII.
} 
of the Arctic. As stated above, the flag State has exclusive enforcement jurisdiction over its national vessels on the high seas according to Article 92 LOSC. On the high seas international law does not allow any State other than the flag State to assert enforcement jurisdiction over violations of fisheries laws and regulations. Such enforcement jurisdiction includes interfering with the navigation of the vessel (interdiction or interception), boarding and searching the vessel, and may culminate in diverting the vessels to its ports and seizing them there. There are two general exceptions to this exclusive enforcement jurisdiction of the flag State and these are the right of visit under Article 110 LOSC and the right of hot pursuit under Article 111 LOSC, which will not be examined in the context of the present enquiry. Also, nothing may impair the inherent right of the flag State to consent to such enforcement powers by another State either through signing a treaty to this effect, ${ }^{136}$ or by granting its consent on an ad hoc basis.

\section{The Right of Approach and Its Relevance to MCS in Arctic Fisheries}

As a prelude to any enforcement at sea, including inspection of vessels, States must have the necessary information at their disposal that a certain vessel is engaged in IUU fishing to take enforcement action. Such information or intelligence is a critical element for law enforcement purposes in general, including for combatting IUU fishing, ${ }^{137}$ and the need to gather such intelligence ranks high in the maritime security policy of many coastal States. ${ }^{138}$ As to the legal parameters of such intelligence on the high seas, it is true that even though international law of the sea does not permit interference with the navigation of foreign-flagged vessels, save in exceptional circumstances, the same does not hold true in respect of other monitoring measures, which may include modern means. According to a contemporary commentator,

'a warship may inspect it [a foreign vessel] from a safe distance to determine its name, flag, and home port, receive and review any

\footnotetext{
${ }^{136}$ See Article 110 (1) chapeau LOSC.

137 See generally N Klein, Maritime Security and the Law of the Sea (Oxford University Press, Oxford, 2011) 211.

${ }^{138}$ See, inter alia, N Klein, 'Intelligence Gathering and Information Sharing for Maritime Security Purposes under International Law', in N Klein, J Mossop, D Rothwell (eds), Maritime Security: International Law and Policy Perspectives from Australia and New Zealand (Routledge, Abingdon, 2010) 225-241.
} 
data the vessel may be emitting from its automatic identification system (AIS) or long range identification and tracking (LRIT) equipment, perhaps scan other electromagnetic emissions if so equipped, and finally hail it on the radio'. ${ }^{139}$

In the context of the present enquiry, reference should be made to the NEAFC Scheme and the use of vessel monitoring systems (VMS) for all fishing vessels of the contracting parties in the Regulatory Area, which comprises part of the Arctic high seas. In particular, Article 11 of the NEAFC Scheme states that:

(e)ach Contracting Party shall implement a vessel monitoring system (VMS) for its fishing vessels exceeding 20 metres between perpendiculars or 24 metres overall length which fish, or plan to fish, in the Regulatory Area and:

a. require its fishing vessels, fishing in the Regulatory Area, to be equipped with an autonomous system able to automatically transmit messages to a land-based fisheries monitoring centre (FMC) allowing a continuous tracking of the position of a fishing vessel by the Contracting Party of that fishing vessel in conformity with the specifications and schedule set out in Annex VII;

b. ensure that the satellite device shall enable a fishing vessel to communicate by satellite to the Contracting Party messages relating to the following data [inter alia] the vessel identification; the most recent geographical position of the vessel (longitude, latitude)...; the date and time of the fixing of the said position of the vessel; the speed and course at the time of fixing of the said position of the vessel. ${ }^{140}$

A violation of this duty is considered as a 'serious infringement' of the NEAFC Rules under Article 29 (e) of the NEAFC Scheme and may be followed by inspection within 72 hours, diversion to port and other measures. ${ }^{141}$

\footnotetext{
${ }^{139}$ C Allen, Maritime Counterproliferation Operations and the Rule of Law (Praeger Security International, Westport, 2007) 82-83.

${ }^{140}$ See Article 11 (1) of the NEAFC Scheme. Also an obligation to install and operate a VMS is incumbent upon the cooperating non-contracting parties pursuant to Article 34 of the NEAFC Scheme.

${ }^{141}$ See Article 30 of the NEAFC Scheme.
} 
It follows therefore that for the parties to the NEAFC, as well as for cooperating third States, there is a clear obligation to implement a VMS. ${ }^{142}$ For third-State vessels that are not under such obligations according to their national legislation or other applicable instruments, ${ }^{143}$ as well as for vessels fishing in areas of the Arctic outside the Regulatory Area of the NEAFC, any intelligence should be secured by other means, including the traditional right of approach.

It is in this regard that the use of earth observation systems, like satellites, could be of importance, especially for remote areas of the Arctic Ocean. Indeed, it is widely recognized that the use of such systems in the Arctic should be prioritized, 'as earth observation is crucial for Arctic monitoring, as the groundbased station networks are sparsenand lined up on the edges of the Arctic area' ${ }^{144}$ The EU seems to be well placed to support Arctic-relevant maritime infrastructure. As was stated in the most recent EU Commission communication on 'an integrated European Union policy for the Arctic',

the operational infrastructure and services of Copernicus will provide input to Arctic research activities, including weather monitoring, monitoring of climate variables and ice thickness, and improved ocean modelling. In addition, the European Commission will support the implementation of the Svalbard Integrated Arctic Earth Observing System —a multidisciplinary and multinational research infrastructure that is geographically distributed across Svalbard which will contribute to future pan-Arctic monitoring. ${ }^{145}$

\footnotetext{
142 See for the corresponding requirement of satellite-tracking devices on EU fishing vessels, Articles 18-28 of Commission Implementing Regulation (EU) No. 404/2011 of 8 April 2011 laying down detailed rules for the implementation of Council Regulation (EC) No. 1224/2009 establishing a Community control system for ensuring compliance with the rules of the Common Fisheries Policy, OJ L 112, 30.4.2011.

143 See, e.g., the IMO-based obligations concerning Automatic Identification Systems and LongRange Identification and Tracking Systems that may be applicable to certain vessels of certain tonnage. See further information for AIS at <www.imo.org/OurWork/Safety/Navigation/Pages/AIS.aspx.> and for LRIT at <www.imo.org/OurWork/Safety/Navigation/Pages/LRIT.aspx.>.

${ }^{144}$ See M Strahlendorff, S Duyck, J Gille, A Leonenko, T Koivurova, M-Theres von Schickfus, A Stępień and J Thomas, 'Climate Change in the Arctic', in A Stępień T Koivurova and P Kankaanpää (eds), The Changing Arctic and the European Union (Brill, Leiden, 2016) 57-80, at p. 78.

145 Joint Communication of the European Commission and High Representative of the European Union for Foreign Affairs and Security Policy of 27 April 2016 to the European Parliament and the Council, 'An integrated European Union policy for the Arctic', JOIN(2016) 21 final, p. 6;
} 
The Right of Visit and Inspection Programmes

Under Article 110 LOSC, the right of visit is accorded to warships against only those vessels reasonably suspected of having engaged in certain proscribed activities, such as piracy, absence of nationality, or slave trade. ${ }^{146}$ Illegal fishing is not contemplated by the LOSC as a specific ground for the right to visit of a foreign vessel. In consequence, the only relevant heading under Article 110 LOSC is the 'absence of nationality'. Indeed, often unregulated fishing is conducted by stateless vessels, ${ }^{147}$ in which case Article 110 (1) (d) LOSC applies. It is pursuant to this provision that warships or other duly authorised vessels of any State may exercise the right of visit on these vessels. However, it is not certain how many stateless vessels do or will navigate in the Arctic high seas.

In addition, by virtue of Article 110(1) LOSC, other forms of interference can by conferred by treaty on a variety of subjects. ${ }^{148}$ Accordingly, States have concluded numerous multilateral and bilateral agreements that provide for the right of visit on the high seas with a view to addressing various challenges and suppressing illegal activities, including IUU fishing. Of particular relevance is the Fish Stocks Agreement, which grants interdiction powers to State parties under certain conditions. State parties to the said Agreement must permit access to duly authorised inspectors from other States consistent with sub-regional and regional schemes of cooperation. The interception and inspection regime is laid down in Articles 21 and 22 and applies in the absence of boarding and inspection procedures being developed within an RFMO. The innovation of the Agreement is that this inspection regime applies to vessels within high seas areas under the competence of an RFMO, irrespective of whether the flag State of those vessels is

available at http://eeas.europa.eu/archives/docs/arctic_region/docs/160427_joint-communicationan-integrated-european-union-policy-for-the-arctic_en.pdf; accessed 7 August 2017.

146 See R Churchill and V Lowe, International Law of the Sea (Manchester University Press, Manchester, 1999) 203.

147 See the definition of 'unregulated fishing' in Article 3 IPOA-IUU.

${ }^{148}$ Both the Geneva Convention on the High Seas (Geneva, 29 April 1958, in force 30 September 1962, 450 UNTS 11) and the LOSC contain the exception 'where acts of interference derive from powers conferred by treaty'; see Arts. 22(1) and 110(1), respectively. 
a member of the organisation or the arrangement; it suffices that the flag State is bound by the Fishing Stocks Agreement. However, as noted by Klein,

at each stage, the flag State's authority to conduct enforcement action holds sway over the actions of the inspecting State ... Moreover, a core weakness of this regime ultimately rests in the fact that is only available in relation to vessels registered to state parties to the treaty. The ability of vessels to re-flag to avoid such obligations will thereby reduce the effectiveness of enforcement measures designed to improve the conservation and management of fish resources. ${ }^{149}$

In any case, the Fish Stocks Agreement is a very interesting treaty in terms of treaty law, in the sense that even though it recognises and anticipates the adoption of specific measures and boarding procedures in the context of RFMOs as lex specialis, it still provides for inspection of vessels flying the flag of States parties to that Agreement that are not members of these organisations. Hence, it obliges them to cooperate in the conservation and management of certain fish stocks and to abide by measures adopted under the authority of an instrument that is res inter alios acta for them. ${ }^{150}$ However, the Agreement is very careful to set forth that any enforcement measures against delinquent vessels pursuant to the Agreement are contingent upon a 'serious violation' of the provision of the Agreement to which the flag State concerned is party (Article 21, para 11).

In the Arctic, the NEAFC grants the right for inspection on the high seas vis-à-vis Member States. According to Article 15 (2) of the NEAFC Scheme, each Contracting Party shall ensure that NEAFC inspectors from another Contracting Party shall be allowed to carry out inspections on board those of its fishing vessels to which this Scheme applies. Furthermore, it shall adopt measures obliging the masters of the fishing vessels to co-operate with the NEAFC inspectors and to ensure their safety throughout the inspection.

\footnotetext{
${ }^{149}$ Klein (n 137), at pp. 139-40.

${ }^{150}$ See Arts. 34-38, VCLT.
} 
Furthermore, the NEAFC Scheme sets out detailed rules on the means of inspection ${ }^{151}$ and its procedure. ${ }^{152}$ This applies to fishing vessels of the parties and of the cooperating non-contracting parties and not to third States.

As to third States, in line with the principle of exclusive jurisdiction of the flag State on the high seas (Article 92 LOSC), the NEAFC does provide for inspection procedures thereon only pursuant to the consent of the flag State. By virtue of Article 38 (1) of the NEAFC Scheme,

NEAFC inspectors shall request permission to board and inspect non-Contracting Party vessels sighted or by other means identified by a Contracting Party as engaging in fishing activities in the Convention Area. If the master of the vessel consents to be boarded the inspection shall be documented by completing an inspection report as set out in Annex XIII.

If the master does not consent for his vessel to be boarded and inspected, the vessel is presumed to have engaged in IUU activities. ${ }^{153}$

In addition to the consent of the flag State or the master under the aforesaid Article, ${ }^{154}$ applicable to the NEAFC Convention Area, any inspection of a fishing vessel would be justified by the absence of nationality of the vessel in question (Article 110 LOSC), which, as said, is questionable. A third avenue could be the use of the Fish Stocks Agreement boarding provisions, as applicable, because under Article 21(3) of this Agreement,

[i]f, within two years of the adoption of this Agreement, any organization or arrangement has not established such procedures, boarding and inspection pursuant to paragraph 1, as well as any subsequent enforcement action, shall, pending the establishment of such procedures, be conducted in accordance with this article and the basic procedures set out in article 22 .

\footnotetext{
${ }^{151}$ Article 16 of the NEAFC Scheme.

152 Article 18, ibid.

153 Article 38 (3), ibid.

154 The authority of the master to give consent to boarding operations (commonly referred to as 'consensual boarding') is not without controversy under the law of the sea. For the relevant discussion see E Papastavridis, Interception of Vessels on the High Seas (Hart, Oxford, 2013) 6366.
} 
Thus, in the absence of boarding provisions established in the Regulatory Area, the Fish Stocks Agreement could provide the requisite legal basis only for the Regulatory Area of the NEAFC and for vessels flying the flag of a party to the Fish Stocks Agreement that are engaged in fishing of straddling stocks or highly migratory species, like tuna. In areas beyond the scope of the NEAFC, the ad hoc consent of the flag State and, in theory, statelessness, are the only legal bases for any interception of IUU vessels.

\section{Conclusion}

Even though there is no fishing activity within the central Arctic Ocean at present, commercial fishing activity does occur in the high seas areas of the North Atlantic and North Pacific, and within the EEZ of the Arctic coastal States. Climate change will most probably lead to an increase in fishing activity, through the reduction in sea ice, opening up new areas of the Arctic Ocean to fisheries, including the Central Arctic Ocean. The coastal States in the region have not remained idle, especially with respect to the Central Arctic Ocean. The 2015 Oslo Declaration declared a moratorium on fishing in the Central Arctic Ocean. It has been followed by intensive negotiations - still ongoing - for the signing of a legally binding agreement to prevent unregulated high seas fisheries therein. Nevertheless, this agreement will not establish an RFMO in that part of the Arctic, although, apparently, soon there will be the need for such an organization.

What seems to be missing from both the ongoing negotiations on the Draft Agreement for the Central Arctic and the scholarly literature is reference to fisheries enforcement in the Arctic Ocean. MCS, as well as enforcement fisheries laws and regulations, are of paramount importance for many reasons, including for combatting the scourge of IUU fishing. It is true that currently fisheries enforcement in the Arctic high seas is not a pressing issue, due to the lack of any fishing in the Central Arctic and the limited and regulated fishing in other parts of the Arctic high seas. However, it is certain that the more commercial fishing occurs in the Arctic, the more States in the region will have to deal with enforcement issues. 
Accordingly, this article identified the most effective tools that could be employed for fisheries enforcement purposes and discussed their potential application in the Arctic context. Such tools include, inter alia, port State control measures, flag State measures, such as fishing vessels' registration, and measures by third States, including inspections at sea. These were discussed against the background of general international law of the sea and of particular treaty regimes applicable to the region, including the NEAFC. The EU and its Member States certainly could play an active role in such enforcement processes, not only because EU Member States are fishing in the region and because one-third of fish caught in the Arctic is sold on the European market, but also for the reason that the EU has already a very robust MCS and enforcement toolbox.

As this was rather an academic exercise due to the paucity of Arctic high seas fisheries, it will be mostly up to the Arctic States themselves to identify the tools that they consider to be most useful. In this regard, it is disappointing that in the draft agreement on the Central Arctic Ocean, the States involved opted not to address compliance and enforcement questions. They may leave such issues for a future RFMO in the region, which remains to be seen. 